\title{
Vying Efficacy of Livol, Livotal, and Hepato Promoter on Performance and Immune Response of Broiler
}

\author{
Sajid Hussain Qamar ${ }^{1, *}$, Ahsan ul Haq ${ }^{1}$, Fawwad Ahmad ${ }^{1}$, Shahid ur Rehman ${ }^{1}$, Pervez Akhtar ${ }^{2}$, \\ Naeem Asghar ${ }^{1}$, Ghulam Abbas ${ }^{1}$ \\ ${ }^{1}$ Department of Poultry Science, University of agriculture, Pakistan \\ ${ }^{2}$ Department of Animal Breeding and Genetics, University of agriculture, Pakistan
}

Copyright (C) 2015 Horizon Research Publishing All rights reserved.

\begin{abstract}
The aim of the present study was to compare the efficacy of commercial herbal products on performance and immune response of broiler. One hundred twenty chicks were randomly divided into 12 experimental units (replicates) having ten chicks each. These experimental units were allotted to four treatment groups $\left(T_{1}, T_{2}, T_{3}\right.$ and $\mathrm{T}_{4}$ ) such that each treatment has three replicates. Group $\mathrm{T}_{1}$ was without supplementation of any commercial herbal product and served as control while the birds in group $T_{2}$, $\mathrm{T}_{3}$ and $\mathrm{T}_{4}$ were supplemented with commercial herbal products i.e. Livol, Livotal, and Hepato promoter @ $1 \mathrm{ml}$ per 2 liter water, $1 \mathrm{ml}$ per 4 liter water, $1 \mathrm{ml}$ per 4 liter water respectively. Supplementation of different commercial herbal products by water during 2-5 weeks of age significantly $(\mathrm{P}<0.05)$, improved weight gain $(6.36-$ $12.37 \%)$, consumed less feed $(2.62-3.09 \%)$ improved feed conversion ratio $(9.53-14.29 \%)$ and lowest mortality rate (3.33\%). Supplementation of different commercial herbal products exhibited non-significant effect on dressed weight, relative weight of heart, liver, spleen, gizzard, pancreas and intestine of broiler. However, ND and IBD antibody titer was improved significantly $(\mathrm{p}<0.05)\left(\mathrm{T}_{1}\right)$. The birds using water supplemented with Hepatopromoter fetched the highest profit.
\end{abstract}

Keywords Livol, Livotal, And Hepato Promoter, Broilers, Performance, Immune Response, Growth Promoter

\section{Introduction}

Poultry meat is a very nutritive source of protein and other energetic nutrients that are long chain fatty acids, vitamin B complex, iron and zinc, which resulted in all over the world gradually acceptance of chicken meat and its products. Vitamins and minerals which are present in poultry meat help to boost the immune system, digestion, metabolic breakdown, development of healthy skin and strengthen bones, build, maintain and repair body tissues. More Selenium is present in breast of chicken as compared to beef and lamb. Differences in nutritive values showed that there is a capability of chicken digestive system to take up cheap nutrients from feeds residues and deposit them in the high nutritive value meat.

Commercial poultry farming in Pakistan is challenged with many problems like Coccidiosis, salmonellosis etc. and huge losses due to contamination of feed with pathogenic bacteria and their related effects in birds, such as poor weight gain or even increased mortality are major obstructions in its progress [34]. To overcome these problems antibiotic have been used in poultry for the past four decades to improve growth performance of poultry and to protect them from the antagonistic effects of pathogenic and non-pathogenic enteric microorganisms. The total use of antibiotics as a growth promoter is estimated to be 4500 tons per year. But their usage in poultry industry is intensively controversial because the expansion of bacterial conflict and potential consequence on the human health [3,20,31].

Using antibiotics as growth promoters has remained under scrutiny for many years [30]. Present poultry industry is paying more attention towards addressing public concern for environmental and food safety issues. Therefore the non-recommended use of antibacterial in poultry feed has been restricted or completely banned. Sub- therapeutic levels of antibiotics have been prohibited by the European Union to avoid diseases resistance, initially with a ban on Avoparcin in 1997 followed by prohibition of virginamycin, bacitracin, spiromycin, and tylosine in 1999. European Union has strictly expelled the usage of antibiotic in poultry since January 2006. Therefore, antibiotics substitutes are of great interest to those associated with poultry industry. Herbs and herbal products, prebiotic, probiotic, enzymes, immune-modulators, microflora enhancers and organic acid should be taken into account as an alternative of antibiotics. $[23,7,6,39,1629]$.

In such situations herbs, spices, and numerous plant extracts have received better attention as a probable 
antibiotic growth promoter's replacement. As an alternative of antibiotic growth promoters medicinal plants are the most popular options. In these plants like neem, garlic, ginger, kalongi, turmeric, cumin, coriander, oregano, rosemary, sage, thyme, clove, mustard, cinnamon, savory, sea-buckthorn and mint etc. have been studied $[8,25,3\}$. Which have showed positive effect. In these studies different parts of plants and their extracts viz. oil, leaves, bark, seed, roots and other vegetative parts etc. have been experimentally used in poultry species. Growth promotion, antibacterial, anti coccidial, anti-parasitic, anti-fungal, antitumor, anti-cancer, pesticide, immune booster and immunogenic properties of these candidate species have been investigated [38]. The World Health Organization considered that $80 \%$ of the earth's populations trust on traditional medicine for their prime healthcare, needs, and utmost of this therapy involves the use of numerous plant extracts or their active constituents $[15,40]$.

Herbal medicines can be serve as safer alternatives as growth promoter due to their suitability and preference, lower cost of production, reduced mortality, reduced risk of disease, minimum health hazards and environment friendliness. Some medical companies have tried to prepare commercial herbal products which are in the market and needs different biological trails to test their claims. Some of the reports have demonstrated improvement with respect to final weight gain, feed efficiency, lowered mortality and increased livability in poultry birds [17,4]. Also such commercial herbals products preparations have shown beneficial effects against diseases due to feed contaminants like aflatoxin, toxicity caused by chemical drugs and fetch extra profit per bird [9]. Our country abounds in herbal wealth and innumerable plants which have interesting pharmacological properties which needs exploitation by the modern methods. Therefore, it is matter of interest to try some commercial indigenous medicinal products in poultry farming.

\section{Materials and Methods}

The research project was conducted at Poultry Research Center, University of Agriculture, Faisalabad during the month of March and April,2014. One hundred and twenty day old broiler chicks were divided into 12 experimental units of 10 chicks each and were further allotted to five treatment groups (A, B, C, D and E) such that each group received three replicates. The chicks were raised in a room having 28 pens. The chicks under different experimental treatments were kept in separate pens measuring $5 \times 3 \times 2.5$ feet, which were disinfected and white washed before the start of experiment. The birds were treated without or with supplementation of commercial herbal products (Table 2). Commercial herbal products composition used in experiment is shown in Table 1. The starter and finisher rations were fed adlibitum to all treatment groups, from 1-21 and 22-35 days of age, respectively. All the birds were kept under similar managemental conditions like space, light, temperature, ventilation and relative humidity etc. All the birds were be vaccinated according to the recommended schedule.

The data regarding to initial body weight, weekly body weight gain, weekly feed consumption, feed conversion ratio (feed intake/weight gain), daily water intake, and mortality wre collected to check performance of birds. The experiment was terminated at the age of 35 days. After which three birds/replicate were slaughtered by cutting the throat (Hallal method according to Islam) followed by complete bleeding. Live birds were weighed, slaughtered and scalded by immersing them into the water at temperature ranging from 180-190 $\mathrm{F}^{0}$ for half minute (Jull, 1976). After that, the birds were manually plucked by hanging them on shackles by their feet and obtained the minor body organs weight. The slaughtered birds were cut, opened and the offals were removed. The rest was taken as dressed weight. Blood samples ( 2 birds/ replicate) were collected at $28^{\text {nd }}$ and $32^{\text {th }}$ day of age to determine the immune response against the ND and IBD [21,32]. The results obtained from the trial were statistically analyzed [37].

Table 1. Composition of commercial herbal products used in experiment

\begin{tabular}{|c|c|}
\hline $\begin{array}{c}\text { Commercial Herbal } \\
\text { Product }\end{array}$ & Product Composition \\
\hline Livol (U.M. Enterprises) & $\begin{array}{l}\text { Solanum nigrum,Terminalia } \\
\text { arjuna,Terminalia chebula,Andrographis } \\
\text { paniculata,Withania somnifera, } \\
\text { Azadirachta indica,Eucalyptus alba, } \\
\text { Mangifera indica, Betafin. }\end{array}$ \\
\hline $\begin{array}{l}\text { Livotal (Nawan } \\
\text { Laboratories) }\end{array}$ & $\begin{array}{l}\text { Solanum nigrum, Mangifera indica, } \\
\text { Andrographis paniculata, Withania } \\
\text { somnifera, Eucalyptus alba, Terminalia } \\
\text { arjuna, Terminalia chebula, Azadirachta, } \\
\text { Natural Betaine, Silymarin (Milk Thistle), } \\
\text { Tamarix Gallica, Zarshak, Dhmasa, } \\
\text { Swertia Charata Busch and HA, Halilah } \\
\text { Siah. }\end{array}$ \\
\hline $\begin{array}{c}\text { Hepatopromoter } \\
\text { (Forward Solutions ) }\end{array}$ & $\begin{array}{l}\text { Cynara Scolymus L.(Artichoke extract as } \\
\text { major constituent in composition) Vit. } \mathrm{B}_{1} \text {, } \\
\mathrm{B}_{2}, \mathrm{~B}_{5}, \mathrm{~B}_{6}, \mathrm{~B}_{12} \text {. (use as a preservative). } \\
\text { Nicotinic acid, Biotin, inositol, choline } \\
\text { chloride, sodium propionate, sodium } \\
\text { sorbate, sorbitol. (as a inactive } \\
\text { ingrdients). }\end{array}$ \\
\hline
\end{tabular}

Table 2. Lay out of the experiment

\begin{tabular}{|c|c|}
\hline Groups & Treatment \\
\hline Group $\mathrm{T}_{1}$ & Without commercial herbal product (control) \\
\hline Group $\mathrm{T}_{2}$ & Livol, $(1 \mathrm{ml} / 2$ liter $)$ \\
\hline Group $\mathrm{T}_{3}$ & Livotal $(1 \mathrm{ml} / 4$ liter $)$ \\
\hline Group $\mathrm{T}_{4}$ & Hepato promoter $(1 \mathrm{ml} / 4$ liter $)$ \\
\hline
\end{tabular}

\section{Results}

\section{Broiler Performance at Starter Phase ( $2^{\text {nd }}$ to $3^{\text {rd }}$ weeks)}

Commercial herbal products showed significant effect $(\mathrm{P}>0.05)$ on feed intake weight gain and feed conversion ratio (FCR) in broilers. Maximum weight gain was observed in bird of $\mathrm{T}_{3}$ (Livotal), maximum value of feed 
consumption during 2-3 weeks of age was observed in chicks under $\mathrm{T}_{1}$ (control) whilst treatments $\mathrm{T}_{2}(\mathrm{Livol})$ and $\mathrm{T}_{3}$ (Livotal) exhibited best feed conversion ratio (Table 3 ).

\section{Broiler performance at finisher Phase (4-5 weeks)}

Commercial herbal products showed significant effect $(\mathrm{P}>0.05)$ on feed intake weight gain and feed conversion ratio (FCR) in broilers. Maximum weight gain was noted in birds under treatment $\mathrm{T} 4$ (Hepatopromoter) whilst birds under $\mathrm{T}_{1}$ (control) consumed maximum feed as compared to all other treatments. Broilers which were not given any herbal product poor feed conversion ratio $\left(\mathrm{T}_{1}\right)$ (Table 4).

\section{Broiler Performance (Cumulative Phase)}

Commercial herbal products showed significant effect ( $\mathrm{P}>0.05)$ on feed intake weight gain and feed conversion ratio (FCR) in broilers. Maximum weight gain was noted in birds of treatment $\mathrm{T}_{4}$ (Hepatopromoter) whilst birds of group $\mathrm{T}_{1}$ showed maximum feed consumption and poor FCR (Table 5).

Table 3. Comparative efficacy of commercial herbal productson weight gain, feed consumption and FCR of broilers during 2-3 weeks (8-21 days).

\begin{tabular}{|c|c|c|c|c|c|c|}
\hline \multirow[b]{2}{*}{ Parameters } & \multicolumn{4}{|c|}{ Treatments } & \multirow[t]{2}{*}{ SEM } & \multirow[t]{2}{*}{$\mathrm{P}$ value } \\
\hline & $\begin{array}{c}\mathrm{T}_{1} \\
\text { (Control) }\end{array}$ & $\begin{array}{c}\mathrm{T}_{2} \\
\text { Livol } \\
(1 \mathrm{ml} / 2 \text { liter }) \\
\end{array}$ & $\begin{array}{c}\mathrm{T}_{3} \\
\text { Livotal } \\
(1 \mathrm{ml} / 4 \text { liter }) \\
\end{array}$ & $\begin{array}{c}\mathrm{T}_{4} \\
\text { Hepato-promoter } \\
(1 \mathrm{ml} / 4 \text { liter }) \\
\end{array}$ & & \\
\hline Number of chicks & 30 & 30 & 30 & 30 & & \\
\hline Days of starter phase & 14 (2-3 weeks) & 14 (2-3 weeks) & 14 (2-3 weeks) & 14 (2-3 weeks) & & \\
\hline $\begin{array}{c}\text { Average intial Weight } \\
\text { (g)per chicks }\end{array}$ & 166.66 & 170.5 & 175.5 & 180.66 & & \\
\hline $\begin{array}{l}\text { Average Final live weight } \\
\text { (g)per chicks at } 22 \text { day }\end{array}$ & 806.96 & 881.5 & 888.3 & 879 & & \\
\hline $\begin{array}{l}\text { Average Weight gain } \\
\text { (gm.)per chicks }\end{array}$ & $640.3^{b}$ & $711.5^{\mathrm{a}}$ & $712.8^{\mathrm{a}}$ & $699.0^{\mathrm{a}}$ & 11.6 & 0.05 \\
\hline $\begin{array}{l}\text { Average Feed consumption } \\
\text { (gm.)per chicks }\end{array}$ & $1236.1^{\mathrm{a}}$ & $1196.5^{\mathrm{b}}$ & $1199.0^{\mathrm{b}}$ & $1198.7^{\mathrm{b}}$ & 5.2 & 0.001 \\
\hline FCR & $1.93^{\mathrm{a}}$ & $1.68^{\mathrm{b}}$ & $1.68^{\mathrm{b}}$ & $1.71^{\mathrm{b}}$ & 0.03 & 0.006 \\
\hline Mortality & 3.33 & 0 & 0 & 0 & & \\
\hline
\end{tabular}

a, b, c column means with different superscripts differ significantly at $(\mathrm{p}<0.05)$

Table 4. Comparative efficacy of commercial herbal productson weight gain, feed consumption and FCR of broilers during 4-5 weeks (22-35 days).

\begin{tabular}{|c|c|c|c|c|c|c|}
\hline \multirow[b]{2}{*}{ Parameters } & \multicolumn{4}{|c|}{ Treatments } & \multirow[t]{2}{*}{ SEM } & \multirow[t]{2}{*}{$P$ value } \\
\hline & $\begin{array}{c}\mathrm{T}_{1} \\
\text { Control }\end{array}$ & $\begin{array}{c}\mathrm{T}_{2} \\
\text { Livol } \\
(1 \mathrm{ml} / 2 \text { liter }) \\
\end{array}$ & $\begin{array}{c}\mathrm{T}_{3} \\
\text { Livotal } \\
(1 \mathrm{ml} / 4 \text { liter }) \\
\end{array}$ & $\begin{array}{c}\mathrm{T}_{4} \\
\text { Hepato-promoter } \\
(1 \mathrm{ml} / 4 \text { liter }) \\
\end{array}$ & & \\
\hline Number of chicks & 30 & 30 & 30 & 30 & & \\
\hline Dayof finsher phase & 22-35 (14days) & 22-35 14days) & 22-35(14days) & 22-35(14days) & & \\
\hline $\begin{array}{c}\text { weight }(\mathrm{g}) \\
\text { per chicks at } 22 \text { day }\end{array}$ & 806.96 & 881.5 & 888.3 & 879 & & \\
\hline $\begin{array}{l}\text { Final live weight (g)per } \\
\text { chicks at } 35 \text { day }\end{array}$ & 1748.66 & 1853.1 & 1905.6 & 1958.4 & & \\
\hline $\begin{array}{l}\text { Weight gainper chicks at } \\
35 \text { day }\end{array}$ & $941.6^{\mathrm{b}}$ & $971.1^{\mathrm{b}}$ & $1018.3^{\mathrm{ab}}$ & $1078.8^{\mathrm{a}}$ & 19.5 & 0.03 \\
\hline $\begin{array}{c}\text { Feed consumption } \\
(\mathrm{gm} .) \text { per chicks }\end{array}$ & $2176.5^{\mathrm{a}}$ & $2110.7^{\mathrm{b}}$ & $2123.0^{\mathrm{b}}$ & $2124.5^{\mathrm{b}}$ & 8.4 & 0.003 \\
\hline FCR & $2.3^{\mathrm{a}}$ & $2.1^{\mathrm{ab}}$ & $2.0^{\mathrm{bc}}$ & $1.9^{\mathrm{c}}$ & 0.04 & 0.01 \\
\hline Mortality (\%) & $3.33 \%$ & $3.33 \%$ & 0 & $3.33 \%$ & & \\
\hline
\end{tabular}

a, b, c column means with different superscripts differ significantly at $(\mathrm{p}<0.05)$ 
Table 5. Comparative efficacy of commercial herbal productson weight gain, feed consumption and FCR of broilers during 2-5 weeks (8-35 days).

\begin{tabular}{|c|c|c|c|c|c|c|}
\hline \multirow[b]{2}{*}{ Parameters } & \multicolumn{4}{|c|}{ Treatments } & \multirow[t]{2}{*}{ SEM } & \multirow[t]{2}{*}{$\mathrm{P}$ value } \\
\hline & $\mathrm{T}_{1}$ (Control) & $\begin{array}{c}\mathrm{T}_{2} \text { Livol } \\
\text { (1 } \mathrm{ml} / 2 \text { liter })\end{array}$ & $\begin{array}{l}\mathrm{T}_{3} \text { Livotal } \\
(1 \mathrm{ml} / 4 \text { liter })\end{array}$ & $\begin{array}{c}\mathrm{T}_{4} \\
\text { Hepato-promoter } \\
(1 \mathrm{ml} / 4 \text { liter })\end{array}$ & & \\
\hline No. of Chicks & 30 & 30 & 30 & 30 & & \\
\hline Days of experiment & $\begin{array}{l}28 \text { days }(2-5 \\
\text { week) }\end{array}$ & 28 days(2-5 week) & 28 days(2-5 week) & 28 days ( $2-5$ week) & & \\
\hline $\begin{array}{l}\text { Initial weight (g) } \\
\text { per chicks }\end{array}$ & 166.66 & 170.5 & 175.5 & 180.66 & & \\
\hline $\begin{array}{l}\text { Final live weight } \\
\text { (g)per chicks }\end{array}$ & 1748.66 & 1853.1 & 1905.6 & 1958.4 & & \\
\hline $\begin{array}{c}\text { Weight gain (g)per } \\
\text { chicks }\end{array}$ & $1582.0^{\mathrm{c}}$ & $1682.6^{\mathrm{b}}$ & $1731.1^{\mathrm{ab}}$ & $1777.8^{\mathrm{a}}$ & 24.5 & 0.004 \\
\hline $\begin{array}{l}\text { Feed consumption } \\
\text { (g)per chicks }\end{array}$ & $3412.6^{\mathrm{a}}$ & $3307.2^{\mathrm{b}}$ & $3322.0^{\mathrm{b}}$ & $3323.2^{\mathrm{b}}$ & 13.5 & 0.001 \\
\hline FCR & $2.1^{\mathrm{a}}$ & $1.90^{\mathrm{b}}$ & $1.90^{\mathrm{b}}$ & $1.8^{\mathrm{b}}$ & 0.03 & 0.01 \\
\hline Mortality (\%) & $6.66 \%$ & $3.33 \%$ & 0 & $3.33 \%$ & & \\
\hline
\end{tabular}

a, b, c column means with different superscripts differ significantly at $(\mathrm{p}<0.05)$

Table 6. Comparative efficacy of commercial herbal products on Average values of dressing percentage, relative giblet weights (g organ wt. /100g body wt.), spleen, pancreas and intestinal weight of broilers during 2-5 weeks (8-35 days).

\begin{tabular}{|c|c|c|c|c|c|c|}
\hline \multirow[b]{2}{*}{ Parameters } & \multicolumn{5}{|c|}{ Treatments } & \multirow[b]{2}{*}{$\mathrm{P}$ value } \\
\hline & $\begin{array}{c}\mathrm{T}_{1} \\
\text { (Control) }\end{array}$ & $\begin{array}{c}\mathrm{T}_{2} \\
\text { Livol } \\
(1 \mathrm{ml} / 2 \text { liter }) \\
\end{array}$ & $\begin{array}{c}\mathrm{T}_{3} \\
\text { Livotal } \\
(1 \mathrm{ml} / 4 \text { liter }) \\
\end{array}$ & $\begin{array}{c}\mathrm{T}_{4} \\
\text { Hepato-promoter } \\
(1 \mathrm{ml} / 4 \text { liter }) \\
\end{array}$ & SEM & \\
\hline Live Body weight(g) & 1758.6 & 1859.1 & 1908.6 & 1956.6 & 24.3 & 0.002 \\
\hline Dressing percentage (g) & 60.93 & 62.81 & 62.00 & 62.50 & 0.32 & 0.18 \\
\hline Liver weight (g) & 2.15 & 2.15 & 2.35 & 2.32 & 0.03 & 0.10 \\
\hline Heart weight(g) & 0.42 & 0.44 & 0.47 & 0.48 & 0.01 & 0.43 \\
\hline Gizzard weight(g) & 1.56 & 1.64 & 1.64 & 1.62 & 0.01 & 0.43 \\
\hline Spleen weight $(\mathrm{g})$ & 0.14 & 0.15 & 0.16 & 0.15 & 0.009 & 0.91 \\
\hline Pancreas weight(g) & 0.22 & 0.19 & 0.21 & 0.20 & 0.005 & 0.61 \\
\hline Intestinal weight $(\mathrm{g})$ & 2.86 & 3.40 & 3.39 & 3.31 & 0.09 & 0.13 \\
\hline
\end{tabular}

NS=Non significant

Table 7. (GMT) Mean values of antibody titer against Newcastle disease (ND) and infectious bursal disease (IBD) when used different commercial herbal products from 8-35 days

\begin{tabular}{|c|c|c|c|c|c|c|}
\hline \multirow{3}{*}{ Parameters } & \multicolumn{5}{|c|}{ Treatments } & SEM \\
\cline { 2 - 7 } & $\begin{array}{c}\mathrm{T}_{1} \\
\text { Control }\end{array}$ & $\begin{array}{c}\mathrm{T}_{2} \\
\text { Livol } \\
1 \mathrm{ml} / 2 \text { liter }\end{array}$ & $\begin{array}{c}\mathrm{T}_{3} \\
\text { Livotal } \\
\mathrm{ml} / 4 \text { liter }\end{array}$ & $\begin{array}{c}\mathrm{T}_{4} \\
\text { Hepatopromoter } \\
1 \mathrm{ml} / 4 \text { liter }\end{array}$ & P VALUE \\
\hline $\mathrm{ND}$ & $51.33^{\mathrm{b}}$ & $81.33^{\mathrm{ab}}$ & $81.33^{\mathrm{ab}}$ & $102.67^{\mathrm{a}}$ & 6.8 & 0.02 \\
\hline $\mathrm{IBD}$ & $40.66^{\mathrm{b}}$ & $57.66^{\mathrm{ab}}$ & $72.66^{\mathrm{ab}}$ & $94.00^{\mathrm{a}}$ & 7.5 & 0.04 \\
\hline
\end{tabular}

Mean values with in the same row which have different superscripts, were significantly different $(\mathrm{P}<0.05)$

\section{Mortality}

The total number of birds died during the study was four. Percent mortality in group $\mathrm{T}_{1}, \mathrm{~T}_{2}, \mathrm{~T}_{3}$ and $\mathrm{T}_{4}$ was $6.66 \%$, $3.33 \%, 0 \%$ and $3.33 \%$ respectively. Whereas, no mortality occurred in group $\mathrm{T}_{3}$ postmortem findings of all the dead birds revealed that mortality was due to heat stress because of electric failure.

\section{Slaughter Data}

\section{Dressing Percentage}

Statistical analysis of data showed non-significant effect of commercial herbal products on dressing percentage and minor body parts weight (Table 6).

\section{Immune Response}

Commercial herbal products revealed significant effect on immune response against Newcastle disease (ND) and infectious bursal disease (IBD). Maximum ND and IBD antibody titer was found in birds kept under treatment $\mathrm{T}_{4}$ (Hepatopromoter). 


\section{Discussion}

\section{Broiler Performance}

The results proved that Supplementation of commercial herbal products in broilers significantly $(p>0.05)$ improved the weight gain of the birds. These result are in line with the findings of Goodarzi et al. (2014); Pal. V et al. (2013); Sangoh and Park, (2012); Zanu et al. (2011) who reported that supplementation of neem, chicory, onion, garlic, ginger, anise and rosemary as a natural herbal growth promoters improved the weight gain of broilers $[10,35,42]$. The improvement in weight gain of the birds may be due to inhibition in growth of pathogenic bacteria such as $S$. aureus, E. coli and aflatoxin producing harmful microbes [11].

Supplementation of commercial herbal products showed a significant $(p<0.05)$ effect on the feed consumption of broiler. Result of the present trail are supported by the finding of Safamehr et al. (2013); Durani et al. (2008); Halle et al. (2005) [33,8,12]. Results are also compatible with Waldroup et al. (2013); Onu and Aniebo (2011) who reported a significant effect on feed consumption due to the dietary inclusion of Chicory, Moringa olifera supplemented as a natural herbal growth promoter in broiler ration $[39,26]$. Similar results have also been reported by Nasir (2001) and Osman and El- Barody (1999) when herbs were used in the rations of broilers and layers respectively [24,28].

Average improvement in feed conversion ratio of broilers was 9.53 to $14.29 \%$ by the use of commercial herbal products. The improvement in feed conversion ratio of the birds using herbal growth promoters in their rations may probably be due to the fact that active ingredients of herbal helps in suppressing growth of intestinal bacteria such as $S$. aureus and $E$. coli resultantly in better digestion and absorption [11]. The results are compatible with the findings of Mehmood et al.,(2009) and Ahmad (2005) who found better feed conversion ratio in broilers fed rations containing garlic and kalongi than those maintained on ration without it $[22,2]$.

\section{Slaughter Performance}

Slaughter performance was measured in terms of dressing percentage, weights of intestine, spleen, pancreas and giblet (heart, liver, and gizzard). Supplementation of commercial herbal medicine did not exhibit any effect on the dressing percentage values of the boilers in this study. Abbas (2010) reported non-significant effect of ginger, pepper, and curry leaf powder on dressed weight in broiler [1]. The result of the study are consistent with those observed by Ayssiwede et al. (2011); Osman et al. (2010);Ahmad (2005) and Soliman et al. (1999) who reported that the dietary inclusion of commercial herbal growth promoters containing herbal plants neem and turmeric did not exhibit any effect on the relative heart weight of broilers $[4,27,2,36]$.

\section{Immune response against Newcastle and infectious Bursal Diseases}

Immune system is the most crucial system of the body that helps to maintain good health. It is made up of tissues, lymph nodes and cells, and is principally designed to kill infection causing organisms. When the immune system does not work properly then chances of disease outbreak increases which causes high economic losses. The results of this study proved that supplementation of commercial herbal medicine significantly increased the antibody titer of broilers against Newcastle disease (ND) and Infectious Bursal disease (IBD). The findings of the present study are in line with the findings of Landy et al.(2011); Zafar et al., (2011); Hanieh et al. (2010), Ahmad (2005) Soliman et al. (1999) ; Haq et al. (1999) and Kyo et al. (2001) who reported a significant effect of natural herbal growth promoters on immune response of the broilers supplemented with kalongi neem, garlic, Hypericum perfortum extract and a herbal medicine Livol [21,41,13,2, 36,14,18] . Similarly Ahmad [2] also reported that supplementation of kalongi as herbal growth promoters showed a potential to be used as an alternative to antibiotics and vaccinations. Nidaullah et al. [25] concluded that aqueous extract of Allium sativum bulb (Zingiber officinale) and rhizome plays a very important role as immunostimulant against Coccidiosis, ND, IB and IBD; so, their results are in agreement with this study. The exact reason of improvements in immune response is not known. However, in this study improvement may be due to the polysaccharides and ether extracts of herbs such as neem, which have been found to cause hyperplasia of lymphnodes and increased in the percentage of lymphocytes and neutrophils in blood. Ultimately these constituents improved the immunity against diseases and increased in the antibody titer, when subjected to vaccine (Hailat et al., 2000). The results of the study are also in agreement with the findings of Meraj (1998) who reported significant improvements in antibody titers against Newcastle and infectious Bursal diseases by using neem and garlic in the broilers. Garlic also showed immune booster effect and caused increased immunity level against these diseases.

\section{Economics of Production}

Average production cost per bird inbroiler kept under different treatment groups viz., $\mathrm{T}_{1}$ (control), $\mathrm{T}_{2}$ (Livol), $\mathrm{T}_{3}$, (Livotal) and $\mathrm{T}_{4}$ (Hepatopromoter)were Rs. 218.567, 220.82, 222.5 and 226.54respectively (Table 8), excluding the cost of labor electricity charges and house rent because the experiment was conducted at the poultry Research Center, University of Agriculture, Faisalabad. Miscellaneous cost was calculated by including the estimated cost of litter, disinfectants and vaccination. The average weight gain in experimental groups $\mathrm{T}_{1}, \mathrm{~T}_{2}, \mathrm{~T}_{3}$ and $\mathrm{T}_{4}$ was $1582,1682.6$, 1731.1 and 1777.8 respectively. These broilers were sold at the rate of PRs. 140 per Kg. Profit per bird in the respective groups was found to be Rs., 2.92, 14.74, 19.85 and 22.35 respectively. Water supplementation of commercial herbal medicines was found to be more profitable than control. Broilers reared on Hepatopromoter fetched maximum profit as compared to other groups. 
Table 8. Economics of broiler production kept under different treatment groups supplemented with different commercial herbal products from 8 th to $35^{\text {th }}$ day of age

\begin{tabular}{|c|c|c|c|c|}
\hline Variables & $\begin{array}{c}\mathrm{T}_{1} \\
\text { (Control) }\end{array}$ & $\begin{array}{c}\mathrm{T}_{2} \\
\text { (Livol) } \\
1 \mathrm{ml} / 2 \text { liter }\end{array}$ & $\begin{array}{c}\mathrm{T}_{3} \\
\text { (Livotal) } \\
1 \mathrm{ml} / 4 \text { liter }\end{array}$ & $\begin{array}{c}\mathrm{T}_{4} \\
\text { (Hepatopromoter) } \\
1 \mathrm{ml} / 4 \text { liter } \\
\end{array}$ \\
\hline Chick cost (Rs) & 45 & 45 & 45 & 45 \\
\hline Total feed consumed/bird (Kg) & 3.412 & 3.307 & 3.322 & 3.323 \\
\hline Feed cost/ Kg (Rs) & 45 & 45 & 45 & 45 \\
\hline Feed cost/ bird (Rs.) & 153.567 & 148.82 & 149.50 & 149.54 \\
\hline Medicine cost & 0 & 7 & 8 & 12 \\
\hline $\begin{array}{l}\text { *Miscellaneous charges/ bird } \\
\text { (PRs.) }\end{array}$ & 20 & 20 & 20 & 20 \\
\hline Total cost/ bird (Rs) & 218.567 & 220.82 & 222.5 & 226.54 \\
\hline Average weight gain /bird (g.) & 1582 & 1682.6 & 1731.1 & 1777.8 \\
\hline Sale price/ Kg live (Rs.) & 140 & 140 & 140 & 140 \\
\hline Sale price/ bird (Rs.) & 221.48 & 235.56 & 242.35 & 248.89 \\
\hline Net profit/ bird (Rs.) & 2.92 & 14.74 & 19.85 & 22.35 \\
\hline
\end{tabular}

* Miscellaneous includes brooding cost, cost of litter, disinfection and vaccination

\section{Recommendations, Conclusions and Future Prospects}

Based upon the results of the study, it may be concluded that supplementation of commercial herbal medicine to the broilers can improve efficiency of broiler's feed utilization resulting in to better growth. These findings will help the poultry makers to save expenditure from pocket snatching prices of antibiotics and will help in the production of organic broilers and save the health of mankind from ill effects of residual antibiotics present in the meat.

\section{REFERENCES}

[1] Abbas, R. J., 2010. Effect of using fengreek, parsley and sweet basil seeds as feed addatives on the performance of broiler chickens. Int. J. Poult. Sci. 9; 278-282.

[2] Ahmad, S.A. 2005. Comparative efficiency of garlic, turmeric and Kalongi as growth promoters in broilers. M.Sc (Hons.) Thesis, Dept. of poultry Science, University of Agriculture, Faisalabad Pakistan.

[3] Ansari, J.Z., A. Haq, M. Yousaf, T. Ahmad and S. Khan, 2008. Evaluation of different medicinal plants as growth promoters for broiler chicks. Sarhad J. Agri. 24(2): 323-329.

[4] Ayssiwede, S.B., J.C. Zanmenou, Y. Issa, M. B. Hane, A. Dieng, C. A. A. M. Chrysostome, M. R. Houinato, J. L. Hornick and A. Missohou. 2011. Nutrient composition of some unconventional and local feed resources available in Senegal and recoverable in indigenous chickens or animal feeding. Pak. J. Nutr. 10: 707-717.

[5] Babu, M., K. Gajendran, F. R. Sheriff and G. Srinivasan. 1992. Crown Growfit $\AA$ supplementation in broilers improved their performance. Indian Poultry Review, May 23: $27-28$.
[6] Bentea, M., A. Sara, L. Panta and L. Clapa. 2010. The effect of enzymatic complex allzyme SSF and organic selenium on some growth and consumption indices of broiler turkey. Anim. Sci. Biotech. 43: 9-12.

[7] Choct, M. 2009. Managing gut health through nutrition. Poult. Sci. 50: 9-15.

[8] Durrani, F.R., N. Chand, M. Jan, A. Sultan, Z. Durrani and S. Akhtar, 2008. Immunomodulatory and growth promoting effect of neem leaves infusion in broiler chicks. Sarhad J. Agri., 24(4): 655-659.

[9] Ghosh. T. K. 1992. Efficiency of Liveron a herbal product on counteracting aflatoxin on broiler birds indian poultry review Aug. 33-34.

[10] Goodarzi, M., S.Nanekarani, N. Landy. 2014. Effect of dietary supplementation with onion (Allium cepa L.) on performance, carcass traits and intestinal microflora composition in broiler chickens. Asian Pac J Trop Dis 4: S297-S301.

[11] Hanafy, M. S. and M. E . Hatam. 1991. Studies on the antimicrobial activity of Nigella sativa seed (Black cumin). J. Ethnopharmacology. 34: 275-278.

[12] Halle, I., Thommann, U. Baueramann, M. Henning and P. Kholer, 2005. Effect of graded supplemention of herbs and essential oil in broiler feedon growth and carcass traits. Proceding of the $15^{\text {th }}$ European symposium on poultry nutrtion, Balatonfured, Hungery Sep. 25-29. Pp 292-294.

[13] Hanieh, H., N. Kiyoaki, P. Mingzi, G. Chaogetu, A. Asaki and K. Yasuhiro. 2010. Modulatory effects of two levels of dietary alliums on immune response and certain immunological variables, following immunization, in White Leghorn chickens. Anim. Sci. J. 81:673-680.

[14] Haq, A., K. A. Meraj and S. Rasool, 1999. Effect of supplementing Allium sativum (Garlic) and Azadirachta indica (Neem) leaves in broiler feeds on their blood cholesterol, triglycerides and antibody titre. Int. J. Agri. Bio., 1(3): 125-127.

[15] Jameel. Y. J., A. R Abed.and F. O. Al-Shimmary. 2014. 
Influence of adding garlic and thyme and thier combination on immune response and some blood parameters in broiler.

[16] Kral, M., M. L. Angelovicova, J. Tkacova and M. Kliment. 2011. Probiotic and acetic acid effect on broiler chickens performance. Scientific papers. Anim. Sci. Biotech. 44: $149-152$.

[17] Kumar, O. M., 1991 effect of live-52 syrup on broiler performance in North Eastern Region, Indian poultry review. April: 37-38.

[18] Kyo, E., N. Uda, S. Kasuga and Y. Itakura. 2001. Immunomodulatory effects of aged garlic extract. J. Nutr. 131:1075-1079.

[19] Landy, N., G. G. M. Toghiani and F. F. Yazdi. 2011. Humoral immune responses of broiler chickens fed with antibiotic and neem fruit powder (Azadirachta Indica) as feed additive supplemented diet. Inter. Conf. Life Sci. Tech. 3: 153-155.

[20] Leeson, S. and J. D. Summers. 2005. Commercial poultry Nutrition. $3^{\text {th }}$ ed. Dept. of animal nutrition and poultry science univ. of Guleph Guleph Canada. Nottingham University press Manor farm church lane thramptonNottingham NG110AX, England

[21] MAAF. 1984. Manual of veterinary investigation. Vol $2.3^{\text {rd }}$ ed. Reference Book., Her Majesty's stationary office, London.

[22] Mahmood, M. 2009. Efficacy of crude extracts of garlic (Allium sativum Linn.) against nosocomial Escherichia coli, Staphylococcus aureus, Streptococcus pneumoniea and Pseudomonas aeruginosa. J. Med. Plants Res. 3:179-185.

[23] Maria, T. C. 2012. Effect of supplementation of citric acid in broiler performance. M.sc Thesis Dept. of poultry science, university of agriculture Faisalabad. Pakistan.

[24] Nasir, Z. 2001. Effect of feeding powdered kalongi (Nigella sativa L.) seeds on egg production and quality. M.Sc. (Hons.) Thesis, Deptt. of Anim. Nutr. Univ. of Agri. Faisalabad.

[25] Nidaullah, H., F. R. Durrani, S. Ahmad, I. U. Jan and S. Gul. 2010. Aqueous extract fromdifferent medicinal plants as anticoccidial, growth promotive and Immunostimulant in broilers. J. Agric. Bio. Sci. 1: 53-59.

[26] Onu P. N and A. O. Aniebo. 2011. Influence of Moringa oleifera leaf meal on the performance and blood chemistry of starter broilers. Int. J. food, Agri. and Vet. Sci. 1: 38-44.

[27] Osman, M., H. M. Yakout, H .F. Motawe and W. F. E. ElArab, 2010. Productive physiological immunological and economic effect of supplementation natural feed addative to broiler diets. Egypt Poult. Sci. 30: 25-53.

[28] Osman, A. M. and El-Barody. 1999. Growth performance and immune response of broiler chicks as effected by diet density and Nigella sativa seeds supplementation. Egyptian Poult. Sci. J. 19(3): 619-634

[29] Pal. V, M .Gobade, K .Ravikanth, A Thakur, S Maini. 2013.
Compartive efficacy of supplementation of herbal liver toinc products on growth and perfarmence in broiler. Intl. J. of Advanced Scientific and Technical Research. 6: 808-810.

[30] Ratcliff, J. 2000. Antibiotic bans-a European perspective. Proceedings of the 47 Maryland Nutrition Conferences for Food the Manufacturer, March 22-24 (pp 135-152).

[31] Rosen, G.D.1996. Biotechnology in animal feeds and animal feeding.Ed Wallece R.J.A and Chesssson D. Weinheim: 143172.

[32] Saeed. J. 1990. Effect of Infectious Bursal Disease on Newcastle disease vaccination in layer chickens. MSc. Thesis. Vet. Microbiology. U. A. Faisalabad.

[33] Safamehr, A., F. Fallahand A. Nobakht. 2013. Growth performance and biochemical parameters of broiler chickens on diets consist of chicory (Cichorium intybus) and nettle (Urtica dioica) with or without multi-enzyme. Iran. J. App. Anim. Sci. 3: 131-137.

[34] Saima, M. Z., U. Khan, M. A. Jabbar, A. Mehmud, M. M. Abbas and A. Mehmood. 2010. Effect of lysine supplementation in low protein diets on the performance of growing broilers. Pak. Vet. J. 30: 17-20.

[35] Sangoh, P. and B. S. Park. 2012. Effect of feeding inulin oligosaccharides on cecum bacteria, egg quality and egg production in laying hens. Afr. J. Biotech. 11: 9516-9521.

[36] Soliman, A. Z. A. M., A.A. Gahzalah, S. H. El-Samra, A. M. Atta and Z.M.A.Abdo. 1999. The synergistics effect of either black seed or garlic with fat on broiler performance and immunity. Egypt J. Nutr. Feed. 2:603-620.

[37] Steel, R. G. D., J. H. Torrie and D. A. Dickey. 1997. Principles and Procedures of Statistics. A Biometric Approach. 3rd ed. McGraw Hill Book Comp. Inc. New York, USA.

[38] Subapriya, R. and S. Nagini, 2005. Medicinal properties of neem leaves: A Review. Curr. Med. Chem. - Anti-Cancer Agents. 5:149-156.

[39] Waldroup, A. L., J. T. Skinner, R. E. Heirholzer and P. W. Waldroup. 2013. An evaluation of fructooligosaccharide in diets for broiler chickens and effects on Salmonella contamination of carcasses. J. Poult. Sci. 89: 1651-1662.

[40] WHO (World Health Organization). 2002-2005. Traditional Medicine Strategy. WHO Headquarters Avenue Appia 20, 1211 Geneva 27, Switzerland.

[41] Zafar. M., A. A. Anjum, M. F. Qamar, M. I. Najeeb and A. Maqbool. 2011. Role of herbal polysaccharides as growth promoters in broilers. Sci.Int. 23:157-159.

[42] Zanu, H.K., J.K. Kagya-Agyemang, W.K.J. Kwenin, F.R.K. Bonsu, E. Antwi and S. Ateni. 2011. Physiological Response of Broiler Chickens to Azadirachta indica (Azadirachta indica) and Akakapenpen (Rauvolfia vomitoria) Decoctions: Performance and Carcass Characteristics. Int. J. Poul. Sci. 10 (9): 730-733. 